\title{
The Effect of Task-Based Learning (TBL) Approach on the Students' Listening Comprehension at the Tenth Grade of SMAN 3 Kota Bengkulu
}

\author{
Gio Fresky Hawara \\ English Education Study Program, Department of Language and Art \\ University of Bengkulu \\ giofreskyhawara@gmail.com \\ Syahrial \\ English Education Study Program, Department of Language and Art \\ University of Bengkulu \\ Eric.syahrial@gmail.com \\ Wisma Yunita \\ English Education Study Program, Department of Language and Art \\ University of Bengkulu \\ wismayunita@unib.ac.id
}

\begin{abstract}
This research was aimed to find out the effect of TBL approach on the students' listening comprehension. This research is a quasi-experimental which was conducted at SMAN 3 Kota Bengkulu in academic year of $2018 / 2019$. The population of this research was the tenth grade students distributed in two classes with the total of 68 students. X- MIPA 1 as experimental group consisted of 34 students and X-MIPA II for control group consisted of 34 students. The instruments of this research was a listening test in the form essay and multiple choice consisted of 14 questions. Pre-test and post-test were conducted in both, experimental and control class. The finding of the result showed that the students taught by using TBL approach got higher score than those taught without TBL approach. The result showed that there was a significant effect of using TBL approach on the students' achievement in listening comprehension which was proven by the result of analysis in independent sample t-test was $<0,05$. It means the alternative hypothesis was accepted. Based on the results and discussions at the research, it can be concluded that teaching and learning listening by using task-based learning approach has a positive effect on students' listening comprehension. Some suggestions are proposed, Recommendation to teachers using Task-Based Learning Approach in english teaching and learning process because based on this research and previous research indicate the use of TaskBased Learning Approach give positive impact on english learning and The next researcher is recommended to using Task-Based Learning Approach in other English field like speaking and can be use in other method such as english classroom action research.
\end{abstract}

Keywords: Effect, Task-Based Learning, Students, listening Comprehension. 


\begin{abstract}
ABSTRAK
Penelitian ini bertujuan untuk mengetahui pengaruh pendekatan TBL pada siswa pada pemahaman mendengar siswa. Penelitian ini adalah semi eksperimen yang dilakukan di SMAN 3 Bengkulu tahun akademik $2018 / 2019$. Populasi dari penelitian ini adalah siswa kelas $X$ yang dibagi menjadi dua kelas dengan total 68 siswa. X-MIPA 1 sebagai kelompok kelas eksperimen yang terdiri dari 34 siswa dan X-MIPA II untuk kelompok kelas kontrol yang terdiri dari 34 siswa. Instrumen untuk memperoleh data dalam penelitian ini adalah tes menyimak dalam bentuk esai dan pilihan ganda, terdiri dari 14 pertanyaan. Pra-tes dan post-tes dilakukan pada kedua kelompok yaitu kelas eksperimen dan kelas kontrol. Temuan menunjukkan bahwa siswa yang diajarkan dengan menggunakan pendekatan TBL mendapat skor lebih tinggi dari pada siswa yang diajarkan tanpa menggunakan pendekatan TBL. Hasil penelitian menunjukkan bahwa ada pengaruh yang signifikan dari pengunaan pendekatan TBL terhadap prestasi belajar siswa dalam pemahaman mendengarkan yang terbukti untuk hasil analisis dalam uji- $\dagger$ sampel independen adalah <0,05. Ini berarti alternatif hipotesis diterima. Berdasarkan hasil dan diskusi pada penelitian ini, dapat disimpulkan bahwa pengajaran dan pembelajaran mendengarkan dengan menggunakan pendekatan pembelajaran berbasis tugas memiliki efek positif pada pemahaman mendengarkan siswa. Beberapa saran diusulkan, untuk guru disarankan untuk menggunakan pendekatan pembelajaran berdasarkan tugas dalam peroses pembelajaran bahasa inggris karena berdasarkan penelitian ini dan penelitian sebelumnya telah membuktikan bahwa pendekatan ini memberikan dampak postif dalam pembelajaran bahasa inggris dan untuk peneliti selanjutnya disarankan menggunakan pembelajaran berdasarkan tugas dalam bidang lain seperti berbicara.
\end{abstract}

Kata kunci : Efek, Pembelajaran Berbasis Tugas, Siswa, Pemahaman Mendengarkan.

\title{
Introduction
}

In learning English, there are four main basic skills that students' need to master. Brown (1994) states in learning English process the students should master four skills; they are listening, speaking, reading, and writing. Those skills are interrelated and integrated with each other in learning English. Among the four basic skills, listening is the most communicative activity in daily life. Morey (1991) states in the teaching and learning listening to the learner is expected to listen twice as much as we speak, 
four times more than we read and five more times than we write. It means in English language learning listening is a very basic skill. For the English teacher, it is important to give special attention to this skill in the classroom.

According to the school-based curriculum, the government announced the implementation of curriculum 2013 in every school in Indonesia. This curriculum emphasizes the learners rather than the teacher. It means the learners centered than the teacher-centered in the teaching and learning process (Kemendikbud, 2013). The main point of this curriculum is to provide the student with the ability to receive and distribute the information, express a thought, knowledge, and understanding, feelings and opinions. Hence, it is clear this curriculum focusses on using a language which emphasizes usage in society. Listening and speaking are used in daily life, because these are two of the most used skills to communicate on a daily basis. In order to help the student problem in learning listening, the researcher interested in using Task-based learning (TBL) Approach in teaching and learning listening.

A Task-based learning approach is an approach in which learning revolves around the completion of meaningful tasks. In the TBL approach, the main focus is the authentic use of language for genuine communication. Willis (1996) states "that task is actives where the target language is used by the learners for a communicative purpose (goal) in order to achieve an outcome". According to Nunan (2004), there were seven principles in task-based language learning, they are scaffolding, task dependency, recycling, active learning, integration, reproduction to creation, and reflection. Nunan (2004) in further suggested that there are some components that have to be noticed, those are content (the subject matter to be taught), materials (the things that learners can observe/manipulated), activities (the things that learners and teachers will be doing during a lesson), goals (the teachers' general aim for the task (these are much more general and vague than objectives)), students (their abilities, needs and interest are important), social community (the 
class as a whole and it is sense of groupness). Willis (1996) proposes three steps of TBL framework consist of(1) pre-task : introduced and define the topic, use activities to help students learn useful word and phrases, ensures students understand the task instruction, (2) task cycle: task, planning, and report, and (3) language focus: that consist of analysis and practice.

This research will also be supported by three previous studies that were conducted on task-based learning (TBL). The first research was from Sarinannur (2017) entitle "The Effect Task-Based Learning on Students' Achievement Reading Comprehension". The researcher found that there was a significant effect of using Task-Based Learning on the students' achievement in reading comprehension. It means that by using taskbased learning the score of the students achievment in reading comprehension increase, the increase in scrore can be seen from the percentges of students score during the pre-test and post-test.

The second research was from Nasution (2012) entitle "The Effect of Task-Based Learning Method on Students' Achievement in Writing Procedure Text at SMA N 2 Tanjung Balai". The result of the analysis showed that the score of students achievment in writting procedure text improved, it can be seen from the increase percntages of the student score.

The last research was from Rahmah (2016) entitle "The Use of TaskBased Language Learning to Improve Students' Listening Skill in The Nine Grade of SMPN 8 Yogyakarta in The Academic Year of 2016/2017". Based on the result of this research, it can be concluded, that the students' listening skill improved. With meaningful, challenging and interesting task and good choice of material gained the student's enthusiasm in a listening activity.

This research will be different from the previous studies above, in terms of subject focus, the research design, population, and the material. So, the researcher want to conduct the task-based learning approach in students' listening comprhension, the teaching and learning process hopefully will be more effective. That is why the researcher wants to 
conduct research entitled "The Effect of Task-Based Learning (TBL) Approach on The Students' Listening Comprehension at The Tenth Grade of SMAN 3 Bengkulu".

This research had a research questions was "What is the effect of Task-Based Learning approach on students' listening comprehension at the tenth grade of SMA N 3 Kota Bengkulu ?". The researcher hopes this research will give some influences to the teachers and further researcher.

\section{Method}

This research was categorized as a descriptive quantitative method that used a quasi-experimental design. When conducted educational research, it was not always possible to select or assign a subject at random. The used of applications of various experiments depended on the type of design used. In the case of this research, the researcher decided to use quasi-experimental research because the availability of participants was limited and the number of population in the school was appropriate with the number of samples expected by the researcher.

Moreover, quasi-experimental design chosen by researcher because the participants were organized well in the class where randomization was not possible. According to Creswell (2012), "quasi-experiments include assignment, but not a random assignment of participants to groups".

In this research design, it was applied the pre- and post-test design approach to a quasi-experimental design. The researcher assigned intact groups the experimental and the control treatments, administrated a pretest to both of groups, conducted experimental treatment activities with the experimental group only, and then administrated a post-test to assess the differences of between the two groups (Creswell, 2012).

The population of this research was the tenth grade students of SMAN 3 Bengkulu. Based on researcher interview with the teacher, the tenth grade was the best grade to choose as the population of this research. The topic of this experimental research was correlated to the syllabus of the tenth grade of Senior High School which were listening to song, announcement and phone conversation. Spesificially, the 
researcher took only two classes as the sample in this research. The sample of the research were X MIPA 1 as the experimental class and $X$ MIPA 2 as the control class.

The instruments for collecting data in this research was a set of a listening test. The type of the achievment test were multiple choice and short answer with the study material were listening to a song, announcement and telephone conversation. The listening test was adjusted based on the syllabus of tenth grade. The pre- and post-test were similar between that two classes.

\section{Result and Discussion}

\section{Result}

The main purpose of this research was expected to know what is the effect of task-based learning on students' listening comprehension. This research was done in two sample groups : experimental group and control group. The samples of the research were X Mipa 1 (34 students) and X Mipa 2 (34 students) of SMAN 3 Bengkulu. In experimental group the researcher using task-based learning approach in teaching and learning listening and in control group without using task-based learning approach in teaching and learning listening. This research was done in 6 meetings each group, but 3 meetings taught by teacher and 3 meetings by researcher. The researcher was administered pre-test first, treatment, and post-test at the end of the research. All of data found will be described on this chapter.

The researcher did hypothesis testing to find out whether there is a significant effect of task-based learning approach on student listening comprehension after the treatment.The result of each hypothesis testing result will be described in the following explanation. The independent sample t-test was used to examine the hypothesis proposed. The result of hypothesis on post-test was in the following table: 
Table. Post-Test Analysis Result

\begin{tabular}{|c|c|c|c|c|c|}
\hline $\begin{array}{c}\text { Post-Test } \\
\text { Group }\end{array}$ & $\begin{array}{c}\text { Mean } \\
\text { Score }\end{array}$ & $T$ & Sig. (2-tailed) & $\begin{array}{c}\text { Mean } \\
\text { Difference }\end{array}$ & Conclusion \\
\hline Experimental & 81.00 & \multirow{2}{*}{4.954} & 0.000 & 13.70 & Significant \\
\cline { 1 - 2 } Control & 67.30 & & & & \\
\hline
\end{tabular}

Based on the table above, the result showed $t=4.954$, Sig. (2-tailed) $0.000<0.05$ (hypothesis accepted), indicating that the two groups different significantly, with mean difference was about 13.70. Therefore, it can be concluded that both groups were significant difference, by seeing the mean score in the experimental group is better than the control group. In other words, students who are taught using task-based learning approach gain improvement in listening comprehension rather than students who are not taught using task-based learning approach.

\section{Discussion}

Referring to the research questions, the researcher would like to find out what is the effect of task-based learning approach on students' listening comprehension and not using task-based learning approach on students' listening comprehension. Pre-test and post-test were administered to state that the use of task-based learning approach could give significant improvement to the students' listening comprehension. The result of the test were analyzed by using independent sample t-test on SPSS 16.00 . 
As a result, the researcher found out that the task-based learning approach had an effect or improvement on students' listening comprehension. It could be seen from the improvement of the students' listening comprehension score. There were the significance different score between the experimental class and the control class. The result of this research also supported by several previous studies. First, Sarinannur (2017) found out that there was a significant effect of using Task-Based Learning on the students' achievement in reading comprehension. The score of the students achievement in reading comprehension was increased. Next, Nasution (2012) found that the scores of students' achievement in writing procedure text were improved. The meaningful, challenging and interesting task and good choice of material gained the student's enthusiasm in a writing activity. Statistically, from the result and the previous study above, it can be concluded that task-based learning approach was effective and got positive responses from the students.

Furthermore, by using task-based learning approach, the students can learn more effective and efficient because of students more active in the teaching and learning process, it makes the students easier to understand the material that will be given. Richard and Rodgers (2001), the use of tasks in the learning process can provide a better context because it can involve more students in the learning process so that students have a better chance to learn. They added that giving assignments can be used to support the process of negotiation, modification, changing words and experiments that are very beneficial for the success of second language learning.

Through task-based learning approach, This approach is one of a positive effect on the student's achievement in listening comprehension. By using this approach, the students more active in doing the Task together in their group, the students are brave to report their discussion about the test and it is also make the situation is not boring. Nunan (2004) states that TBL is a need-based approach which focuses on the content selection and emphasizes the learning through interaction in 
the target language. Thus, the most important aspect of the learning process is the personal experience of students. Students will not only focus on language but also on the learning process itself. So, it can be conclude that task-based learning approach is a good technique to be applied in teaching and learnig listening. Through task-based learning approach, the students are able to get the infromation and the main idea in a listening text.

Based on discussion above, the result of this research shows that there were significance effect of using task-based learning approach on students' listening comprehension, it can be seen from the average of the test of the student's score in listening comprehension by using task-based Learning is higher than average of the students who not using task-based learning appraoch. This indicates that the application of using task based learning approach more effective to increase the students' achievement in listening comprehension, it was proven by the improvement of total mean score of the test before and after the treatment.

\section{Conclusion and Suggestion}

\section{Conclusion}

Based on the results and discussions at the research, it can be concluded that teaching and learning listening by using task-based learning approach has a positive effect on students' listening comprehension. It can be seen from the result of post-test, that the mean score of experimental and control group significantly difference. experimental group got higher score than control group. Thus, alternative hypothesis $(\mathrm{Ha})$ is accepted. The result of the research revealed that the students who were taught by using task-based learning approach got better score than those who were taught without task-based learning approach. It can be concluded that task-based learning approach has been successfully implemented as an interesting approach to improve students'listening comprehension. In addition, it can affect students' listening comprehension in term of information, main idea, language structure and specific features in the listening material. 


\section{Journal of English Education and Teaching \\ Volume 3 number 22019}

Pp. 260-270

\section{Suggestion}

Based on the result of this research, some suggestions are proposed as follows :

1. For teachers

Recommendation to teachers using Task-Based Learning Approach in english teaching and learning process because based on this research and previous research indicate the use of Task-Based Learning Approach give positive impact on english learning.

2. For researcher

The next researcher is recommended to using Task-Based Learning Approach in other English field like speaking and can be use in other method such as english classroom action research. The researcher hopes that the research findings can be used as a starting point of the future researchers as a reference.

\section{References}

Brown, H. D. (1994). Teaching by Principles: An Interactive Approach to Language Pedagogy. San Francisco: San Francisco University.

Creswell, J. W. (2012). Educational research: Planning, conducting, and evaluating quantitative and qualitative research (4th ed.). Boston, MA: Pearson.

Kemendikbud. (2013). Dokumen Kurikulum 2013. Jakarta: Kemendikbud.

Morey, J. (1991). Listening comprehension in second/foreign language instruction. In M. Celce-Murcia (Ed.), Teaching English as a second or foreign language (pp. 81-106). Boston, MA: Heinle\&Heinle.

Nasution, A. (2012). The Effect of Task-Based Learning Method on Students' Achievement in Writing Procedure Text at SMA N 2 Tanjung Balai. Tanjung Balai: unpublished skripsi.

Nunan, D. (2004). Task-Based Language Teaching. Cambridge: Cambridge University Press.

Rahmah, D. (2016). The Use of Task-Based Language to Improve Students' Listening Skill in The Nine Grade of SMPN 8 Yogyakarta in The Academic Year of 2016/2017. Yogyakarta: unpublished skripsi. 
Richards, J. C. and Rodgers, T. S. (2001).Approaches and Methods in Language Teaching. Cambridge: Cambridge University Press.

Sariannur. (2017). The Effect Task-Based Learning, Student's Achievement, Reading Comprehension. Medan: unpublished skripsi

Willis, J. (1996). A framework for a Task-Based Learning. Harlow: Longman. 